14) Robert D. Mussey, J. B. J. S. 31 ; 619, 1949

15）立石邦彦他, 整形外科 $9 ; 25$. 昭和 32 年

16) GregoryL. Robillard Amer. J.Surg. 51; 442, 1941

17) Theodor Norley J. B. J.S; 417 420, 1949

18) Howorth Textbook of Orthopedics

19) Lewin The Knee

20) 神中：整形外科学

追 加
九州厚生年金病院 浅 野 冒 男

最近我々も膝関節内側部の離断性骨軟骨炎と思われ る症例に遭遇し, 内側から関節切開を行つたが遊離体 が発見されなかつた。

そこで後方から関節を開いたととろ, 丁度頸骨内顆 部の関節囊附着部のところで関節囊内に abkapselnさ れた状態の遊離体を発見した。

\begin{tabular}{|c|c|c|c|c|c|}
\hline & 鹿児島大学 & 整形外科 & 前 & 田 & 実 \\
\hline & & & 前 & 原 & \\
\hline & & & 長 & 野 & 芳 \\
\hline
\end{tabular}

\title{
A Case of Gout
}

by

\section{Saneyuki Maeda, Makoto Maehara \& Yoshiyuki Nagano}

Department of Orthopedic Surgery, Faculty of Medicine, Kagoshima University

痛風は我か国では稀な疾患であるとされ，現在迄に 未だ 60 数例 の報告をみているに過ぎない. 我々は最 近幼児期に発病したと推察される極めて稀な本疾患の 1 例を観察したので報告する。

\section{证例:}

56 才男子, 木材会社役員.

主訴, 左母趾の腫脹, 疼痛

家族歴, 遺伝的関係, 共に 特記 すべき疾患を 認め ない。

既往歴, 3 才, 6 才, 40 才, 50 才の時に左母趾の腫 脹, 疼痛があり, 各回とも骨髄炎の診断で手術を受け ている.

30 才頃から尿に砂様のものが出て, 40 才の時腎結 石の診断を受けている.

生活歴及び嗜好, 大体美食家と云う程でもなく, 又 特に偏食の傾向むない. 酒は 1 合足らずの晚酌をする が，毎日飲まなりればならないと云う程ではなく．煙 草は若いころから契つていたが, 現在は喫わない.

現病歴, 昭和 34 年 6 月 革の長靴をはいて; 山林の 釦分に行き 2 里位歩いた所, 左母趾に発赤, 畽脹, 疼
痛を来したが放置し, 翌日も同様山に行つた所, 上記 症状著明となつたので, 某医によりペニシリンの注射 と冷湿布を受けた。これで一応症状が軽快したが，未 だ疼痛が残つていたので当科を訪れた。

現症:

\section{全身所見}

体格やや肥満型.耳介その他に痛風結節は認めな い.

\section{局所所見}

左母趾は短縮し, 中足趾関節部の背部及び外側部に 手術瘢痕があり, 発赤, 睡脹は認められないが, 熱感 があり, 圧痛もある. 又内踝の下部に軽度の発赤, 畽 脹, 圧痛がある.

\section{レ線所見}

図 1 亿示す如く, 左第 1 中央骨骨頭及び趾骨の基節 骨底部が殆んど久損し, 変形がみられ該部の陰影は濃 く, 中足骨に軽度の骨萎縮像を認める. 又第 5 中足骨 頭部に一部辺縁鮮明な欠損部がある. その他膝, 足関 節及び中足骨等には何等変化はない。 


\section{这 1}

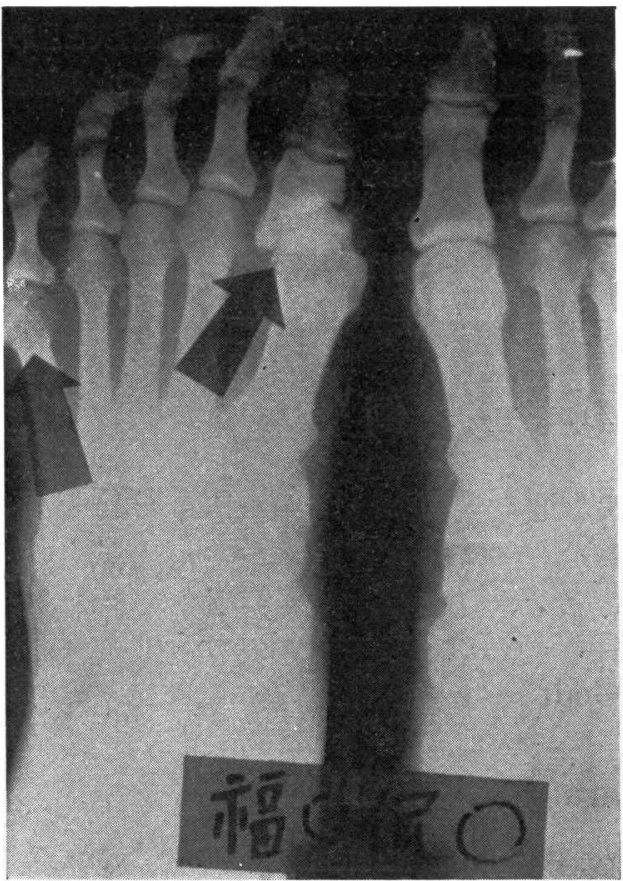

\section{臨床模查成結}

血液一般所見は, 赤掹球数 462 万, 血色素 $92 \%$ （ザー リ一), 白血球数 12,400 , 百分率は，好中桿状核 $28.5 \%$, 好中多核 $44 \%$ ，好酸球 $1.0 \%$ ，好塩基球 $0.5 \%$ ，単球 $0.5 \%$ ，リンパ球 $25.5 \%$ ，血沈值は 1 時間 $70 \mathrm{~mm}, 2$ 時間 $135 \mathrm{~mm}$ 厄, 白血球の増加と血沈值の促進の他は 特記すべき変化はない，血清梅毒反応仕，ワ民反心， 凝集法，ガラス板法いずれも陰性てある。血清蛋白分 劃は $\mathrm{A} / \mathrm{G}$ 比の軽度低下及び める.

尿所見にも特記すべき事項はない。

肝機能検査でも，BSP試験す殆んど正常であり，み るべき機能障害はない.

自律神経機能はアドレナリン試験が強陽性に出たの みでピロカルピン,アトロビン両試験は共に陰性て, 旧い分類に従えば交感神経緊張状態である。

循環機能検査として，心電図を試みたが変化は認め ない.

\section{表 1 血液及び尿中尿酸}

血洞中尿酸量 尿中尿酸量 血中残余紫茲量
$7.6 \mathrm{mg} / \mathrm{dl}$ $0.431 \mathrm{~g} / \mathrm{day}$ $23.6 \mathrm{mg} / \mathrm{dl}$
血清及び尿中の㽷酸は，表 1 に示す通り，血清中尿 酸量 $7.6 \mathrm{mg} / \mathrm{dl}$, 尿中尿酸量 $0,431 \mathrm{~g} / \mathrm{day}$ ，血中残余窒素 量 $23.6 \mathrm{mg} / \mathrm{dl}$ て, 血清尿酸量が增加しているが，その 他は略正常値を示している。

入院後の经過 :

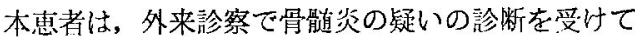
入院したのて，その診断のもとにギプス副子を用い て，8日間化学療法及び冷湿布を行い，その間疼痛は 軽減して来た.入院後 9 日目に変形した骨突出部の切 除と搔爬の目的で手術を行なつた。

手術所見 :

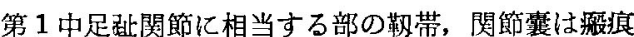
化していた。この般痕をわけて骨膜に達し，骨膜剝離 を行つているうち盤瘎部加ら色色のざらざらした泥状 物を認めた。基節骨のやや蹠側寄りの絬合織に白色 の泥状物が認められ，その部の骨皮質があろくなつて いたので搔爬したが，特記する様な変化は認められな かつた。

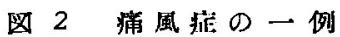

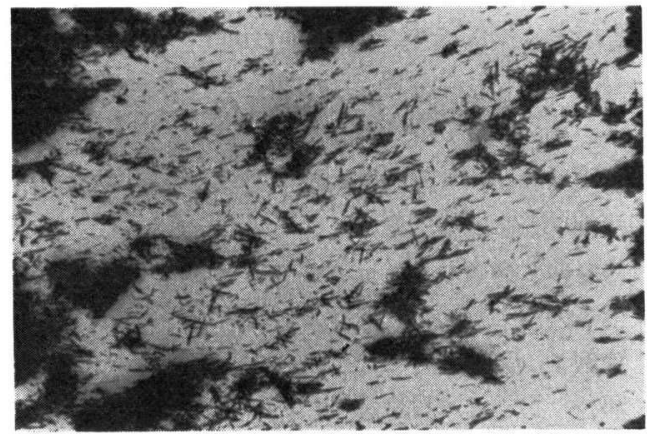

この泥状物を鏡検して見ると図 2 の様に，尿酸ソー ダの針状結晶を認める. 又萎縮を示した部の切除骨 Murexid の反応も陽性であつたので骨䯣炎ではなく， 実は痛風であつた事がわかつた，その為その後は痛風 食を与え，アトフアンを服用させた所，疼痛は全く消 失し患者の都合屯あり術后 21 日目に退院し, 現在経 過観察中である.

\section{考察：}

以上述べた様に，木症例は患者の訴えと変則的なレ 線像一（もつと古左第 5 中足骨には痛風と考えられる 様なレ線が見られるが）一で骨髄炎と䓂断され，手術 によつてはじめて痛風と確診されたものである．幼 垐期に骨䯣资と診断され，しかもその後度々該部の発 
赤, 腫脹, 疼痛等の再発を繰返し, 又その時期に切開を 受けているが; その当時排膿を自覚していないし, 手 術洀璂す綺麗であり，30才台から40才台にかけて腎 結右もあつた事等いろいろ考え合せて見ると, 幼児期 の症状も或いは痛風に依るものではなかつたかと推察 される. 果してそうであつたとすると, この症例は, 発病が幼児期であつたと云う事で非常に稀らしい例で はないかと考える.

痛風の我国に於け一般統計によれば，発症年令は， 21 40才に多く, 大正 9 年森方正が19才 (14才で発 症）の女子の例を 報告している外は, 未だ幼児期に 発症した例は報告されていない. しかし, 欧米に於て は，幼児に発症した報告が稀に見られる。

誩断の面について言及すると, リウマチと誤診され た報告があり, 又本症例の如く骨䯣炎と誤診された点 から考えると, 他にも痛風の典型的症状がないためリ ウマチまたは骨髄炎として見逃されている痛風が案外 多いのではなかろうか。

\section{主 要 交 献}

1）橋本徳次郎 : グレンツゲビート 13. 11. S. 14

2) 原田真夫 : 外科 19. 8. S. 32

3) 医学のあゆみ 14.3. S. 27

4) 久保田仁志：整形外科之災害外科 8. 1. S. 33

5) 橋本他 : 整形外科之災害外科 8. 2. S. 34

6) Philip S. Hench : A Textbock of Medicine

7) Schinz : Roentgendiagnostics

8) John H. Talbott : Arthritis and Rheumatism $2,2,199$
追 加

$\begin{array}{ll}\text { 長崎大整形 } & \text { 朝 長 } \\ & \text { 原田 恵 文 } \\ & \text { 渡辺 徹 }\end{array}$

最近我々は定型的痛風の 1 症例を経験した. 症例; 46 才男子, 職業, 公務員

既往歴； 5 才腎炎， 20 才虫垂炎， 24 才第 1 中足 骨々折。

家族歷；特記すべきものなし.

現病歴；14 15 年前.第 1 中足骨趾骨関節部に疼痛 をむつて発病，現在右第 1 中骨足，左第 5 中足骨小頭 部, 右外踝部, 両踵骨部, 右肘関節, 右示指, 中指, 左脛骨粗面の 8 ケ所代 $1 \sim 8 \mathrm{~cm}$ (直径) の腫瘤を形成 する.

レ線学的にも定型的痛風性变化像を示し, 剔出せる 白㤠状の睡瘤内容物は murexid 反応陽性, 尿酸塩で あり，組織学的にあ痛風所見を呈した。患者には比較 的安静を命じ，プリン体欠乏食を与えている．プレド ニン，ブタゾリジンの内服も炎症々状に比較的に奏効 したが，アトフアン重曹の投与は著効を奏した。

尚患者は腎機能低下あり, 萎縮腎の徵候がある.

発

大阪市大整形 水 野 教 授

痛風症は肉食によつて多いと言われているが，近時 増加しているとは思われない。

\section{手の腱鞘炎 の治 療 経 験}

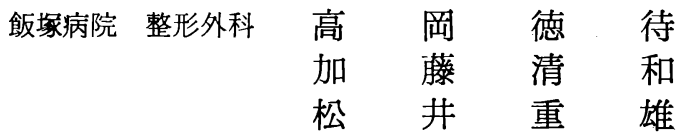

Stenosing Tenosynovitis of the Hand.

by

\section{T. Takaoka, K. Kato. \& S. Matui,} Iizkuka Hospital, Iizuka

\section{いとぐち}

1895 年, de Quervain が橈骨荃状突起部に疼痛を来 し，著しい拇指の運動障害を惹起する長拇指外転笳
睷及び短拇指伸筋睷の狭窄性踺輀炎を記載して以来, 欧米各国では狭窄性腱鞘炎或は弾撥指についての報告 が数多くなされている.然し,わが国においては報告も 少く，農村，工場或は一般家庭において，手をよく使 